\title{
A simple, rapid ELISA method for the detection of DNA antibodies
}

\author{
RP STOKES, A CORDWELL, RA THOMPSON \\ From the Regional Immunology Department, East Birmingham Hospital, Birmingham B9 5ST
}

SUMMARY Employing an enzyme-linked immunosorbent assay (ELISA) technique the serum antibodies against native (double stranded) and denatured (single stranded) deoxyribonucleic acid (DNA) have been measured in various disease groups and a group of blood donor sera.

The ELISA method has been compared with a radioimmunoassay method using native (double stranded) DNA as substrate antigen and a latex-fixation technique using particles coated with soluble deoxyribonucleoprotein (SNP). It is concluded that ELISA offers an economic and reliable alternative to isotope techniques for the assessment of antibody content in systemic lupus erythematosus (SLE) and related disease states for the clinical laboratory.

Deoxyribonucleoprotein is the major component of the nucleus of which the nucleic acid moiety forms the genetic material of the chromosome. Antibodies directed against soluble nucleoprotein and its constituent products, purines, pyrimidines and polynucleotides have been detected in patients with rheumatoid arthritis and associated diseases but antibodies directed against native (double stranded) DNA are a hallmark of patients with systemic lupus erythematosus (SLE). ${ }^{12}$ Antibodies to native DNA have been particularly associated with clinical disease activity. ${ }^{2-4}$ Furthermore, it is generally believed that anti-DNA antibodies are the principal antibody component of circulating immune complexes in SLE and that the pathogenesis of their glomerulonephritis is analogous to experimental serum sickness. ${ }^{56}$ Clinical laboratories are called upon to perform reliable and reproducible tests for the detection of antibodies to DNA and clinicians expect that the results will aid their diagnosis. ${ }^{78}$ Quantitative assays which are sufficiently sensitive for the detection of antibodies specific for DNA have hitherto relied upon a radioimmunoassay method using isotope-labelled DNA which when complexed with antibody is subsequently precipitated with ammonium sulphate or a coprecipitating antibody, ${ }^{9-12}$ or a fluorescein-labelled second antibody in an immunofluorescent staining procedure in-

Accepted for publication 7 September 1981 volving as substrate the kinetoplast of the protozoan Crithidia luciliae. ${ }^{13-16}$

The possibility of enzyme-linked immunosorbent assays has been investigated by several workers using denatured DNA, 17-19 and more recently native DNA coated on to polystyrene tubes with the aid of protamine sulphate. ${ }^{20}$ During the past twelve months Cordis Laboratories, Florida, have developed and marketed two commercial kits using as substrate rigid plastic discs coated with native DNA (Cordia N) or soluble nucleoprotein (Cordia NP). The present paper describes a reliable microtitre plate method suitable for routine screening of test sera for antibody activity directed against both native and denatured DNA.

\section{Material and methods}

MATERIAL

Sera

Blood donor sera (100 samples) were kindly supplied by the Regional Blood Transfusion Service, Birmingham. All other sera were specimens, sent for analysis to this department, which were stored at $-20^{\circ} \mathrm{C}$ containing 1/10 000 sodium azide as preservative. All dilutions of sera were made in a buffer containing: $\mathrm{NaCl} 40 \mathrm{~g} ; \mathrm{Na}_{2} \mathrm{HPO}_{4} 5.75 \mathrm{~g} ; \mathrm{KH}_{2} \mathrm{PO}_{4} 1 \mathrm{~g} ; \mathrm{KCl} 1 \mathrm{~g}$; $\mathrm{NaN}_{3} 1 \mathrm{~g}$; Triton X-100 $50 \mathrm{ml}$; made up to 51 with distilled water. Immediately before use bovine 
serum albumin was added to a final concentration of $1 \mathrm{~g} / 100 \mathrm{ml}$.

\section{Latex agglutination}

Fisher diagnostic kits for DNP antibodies in SLE were purchased from AR Horwell Ltd. Kits were used according to manufacturer's recommendations.

\section{DNA for radioimmunoassay}

Native DNA, from Escherichia coli intrinsically labelled with ${ }^{14} \mathrm{C}$ was purchased from Amersham International as $50 \mu \mathrm{g}$ amounts in $5 \mathrm{ml}$ lots. In order to avoid any denaturation each batch was pipetted into $10 \times 0.3 \mathrm{ml}$ and $10 \times 0.2 \mathrm{ml}$ aliquots immediately upon receipt and stored at $-70^{\circ} \mathrm{C}$. Aliquots were diluted $1 / 10$ in phosphate-buffered saline (PBS) immediately before the test.

\section{DNA for ELISA}

Highly polymerised DNA extracted from calf thymus was used for all tests shown in the text. DNA from alternative sources were compared in the initial stages of this work. These included DNA from rat liver nuclei, $E$ coli and herring sperm. All were purchased from Sigma Chemical Co Ltd.

Residual protein from calf thymus DNA was removed by overnight digestion at $37^{\circ} \mathrm{C}$ of a $5 \mathrm{mg} / \mathrm{ml}$ solution of DNA with $200 \mu \mathrm{g} / \mathrm{ml}$ protease. The final incubation mixture contained $50 \mathrm{~m} M$ trisodium EDTA and $1 \mathrm{~g}$ per $100 \mathrm{ml}$ sodium lauryl sulphate in $0.2 M$ TRIS-HCl buffer at $\mathrm{pH} \mathrm{7 \cdot 4}$. The solution was extracted twice with an isoamyl alcohol: chloroform mixture $(1 / 24 \mathrm{vol} / \mathrm{vol})$. The DNA was recovered from the aqueous phase by carefully rotating a glass rod in the solution after addition of two volumes absolute ethyl alcohol. The "spooled" DNA was washed in $70 \%$ ethyl alcohol, dried and dissolved in PBS.

Denatured DNA was prepared by plunging a tube of native DNA solution into a boiling water bath for $10 \mathrm{~min}$ then rapidly transferring tube and contents to an ice bath. Single stranded DNA was prepared as required from aliquots of native DNA stored at $-20^{\circ} \mathrm{C}$.

\section{Antisera}

The antihuman IgG used as second antibody in the radioimmunoassay technique was raised in this laboratory by injecting rabbits intramuscularly with human IgG. The immunogen was eluted from a DE 52 cellulose column in $0.01 M$ phosphate buffer (pH 8) and emulsified in Freund's complete adjuvant.

Enzyme-labelled antihuman IgG for ELISA was purchased from Miles Laboratories Ltd, and used at a dilution of 1/1000 in Tween-PBS buffer.
Tween-PBS ("Wash") buffer for ELISA

$\mathrm{NaCl} 40 \mathrm{~g} ; \mathrm{Na}_{2} \mathrm{HPO}_{4} 5.75 \mathrm{~g} ; \mathrm{KH}_{2} \mathrm{PO}_{4} 1 \mathrm{~g} ; \mathrm{KCl} 1 \mathrm{~g}$; $\mathrm{NaN}_{3} 1 \mathrm{~g}$; Tween $202.5 \mathrm{ml}$; made up to 51 with distilled water.

\section{Substrate buffer for ELISA}

Diethanolamine $97 \mathrm{ml} ; \mathrm{NaN}_{3} 0.2 \mathrm{~g} ; \mathrm{MgCl}_{2} \cdot 6 \mathrm{H}_{2} \mathrm{O}$ $0.1 \mathrm{~g}$; distilled water $800 \mathrm{ml}$; adjust to $\mathrm{pH} 9 \cdot 8$ using $1 \mathrm{M} \mathrm{HCl}$ and make up volume to $1 \mathrm{l}$. Pellets (5 $\mathrm{mg}$ ) of $p$-nitrophenyl phosphate substrate were purchased from Sigma Chemical Co (one tablet per $5 \mathrm{ml}$ substrate buffer for working solution).

\section{Scintillation fluid for radioimmunoassay}

2:5 diphenyloxazole (PPO) 6.0 g; $1: 4$ di-2,5phenyloxazolyl benzene (POPOP) $0 \cdot 12 \mathrm{~g}$; Triton X-100 $333 \mathrm{ml}$ : xylene (scintillation grade) $666 \mathrm{ml}$.

\section{METHODS}

\section{Radioimmunoassay for antibodies to $D N A$}

To duplicate $0 \cdot 1 \mathrm{ml}$ aliquots ( $\equiv 100 \mathrm{ng}$ ) of ${ }^{14} \mathrm{C}$ DNA in $50 \mathrm{~mm} \times 6 \mathrm{~mm}$ polystyrene precipitin tubes (Sterilin RT20) was added $0 \cdot 1 \mathrm{ml}$ of a $1 / 10$ dilution of serum in PBS pH 7.4. After thorough mixing the tubes were incubated at $37^{\circ} \mathrm{C}$ for $1 \mathrm{~h}$ and then placed at $+4^{\circ} \mathrm{C}$ overnight to allow completion of complex formation. The IgG in each tube was precipitated with the second antibody (rabbit antihuman IgG) allowing incubation at $37^{\circ} \mathrm{C}$ for one hour and $+4^{\circ} \mathrm{C}$ for two hours.

The precipitate was removed by centrifugation and washed by resuspending in PBS and recentrifuging. The washed precipitate was dissolved in two drops of $1 M \mathrm{NaOH}$ at $56^{\circ} \mathrm{C}$ for $30 \mathrm{~min}$ neutralised with $\mathrm{HCl}$ in methanol $(1 \% \mathrm{vol} / \mathrm{vol})$ and quantitatively transferred to a counting vial using scintillation fluid. Counts were made over 10minute periods and the tests calculated as a percentage binding of the total tube. Appropriate positive and negative controls were included in each batch of tests.

\section{ELISA method for antibodies to native and denatured DNA}

To each well of a 96-well microtitre plate was added $0.2 \mathrm{ml}$ of a $1 \%$ aqueous solution of protamine sulphate (Sigma). After $30 \mathrm{~min}$ at room temperature the plate was emptied by simple inversion and washed five times with a jet of distilled water from a plastic wash bottle.

DNA solution $(0.2 \mathrm{ml})$ at a concentration of $10 \mu \mathrm{g} / \mathrm{ml}$ was added to the desired number of wells and allowed to stand at room temperature for 30 min. (For convenience native DNA could be applied 
to one half of each plate and denatured DNA to the remaining half-in this way 48 sera including controls could be tested under identical conditions against both antigens.)

After DNA attachment the plate was washed five times in Tween-PBS buffer and $0.2 \mathrm{ml}$ of each sample applied to the appropriate wells. After further incubation at room temperature for $30 \mathrm{~min}$ the plates were carefully washed five times in TweenPBS buffer and shaken almost dry. An amount $(0.2 \mathrm{ml})$ of $1 / 1000$ dilution of alkaline phosphataselabelled antihuman IgG was pipetted into each reaction well and the plate allowed to incubate at room temperature for a further $30 \mathrm{~min}$.

After washing with Tween-PBS buffer five times the plate was again shaken dry and finally $0.2 \mathrm{ml}$ of $p$-nitrophenyl phosphate solution added to each reaction well. Incubation was allowed to take place at $37^{\circ} \mathrm{C}$ for $20 \mathrm{~min}$ when the reaction was halted by the addition of $0.05 \mathrm{ml}$ of $2 \mathrm{M} \mathrm{NaOH}$. Hydrolysis of the substrate to $p$-nitrophenylate was measured by determination of the absorbance at $410 \mathrm{~nm}$ on a Dynatech automatic plate reader. Appropriate positive and negative sera together with a "no serum" blank were included in each batch of tests.

\section{Results}

\section{METHOD CONTROLS}

In an attempt to demonstrate that positive tests observed in the microtitre wells were due to reaction of enzyme-linked anti-IgG reacting with antibodies directed against DNA antigen a series of controls, including inhibition assays, were set up.

\section{Use of protamine sulphate}

In our ELISA method, omission of the protamine sulphate incubation stage resulted in total negative tests. In a separate series of tests it was shown that in the absence of protamine sulphate at least 16 hours were required for adequate binding of denatured DNA; furthermore, for native DNA it took as much as four days to achieve comparable colour intensity and reproducibility from a positive control serum (see Fig. 1).

Pretreatment with protamine sulphate for $15 \mathrm{~min}$ or more facilitated maximum binding of DNA in $30 \mathrm{~min}$.

\section{Inhibition of reactions using soluble antigens}

In inhibition experiments, sera that were native DNA-positive were inhibited by pretreatment with free double stranded antigen; furthermore, sera that were denatured DNA-positive were inhibited with free single stranded antigen. Not surprisingly,

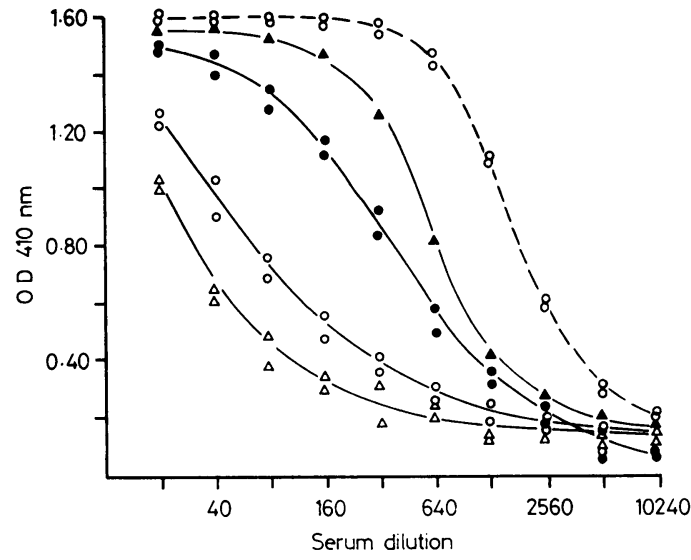

Fig. 1 Using one positive control serum at the dilutions indicated ELISA was carried out in parallel on four microtitre plates coated with native DNA for $24 \mathrm{~h}$ $(\triangle-\triangle) ; 48 h(\bigcirc-\bigcirc) ; 72 h(\bigcirc-0)$ and $96 h$ $(\Delta-\Delta)$ respectively. The colour intensity and reproducibility obtained are represented graphically together with similar results obtained from a microtitre plate coated with denatured DNA for $24 h\left(\bigcirc_{--} \bigcirc\right)$.

some cross reaction occurred, resulting in absorption of antibodies to single stranded DNA using free native DNA and absorption of antibodies to native DNA using free denatured DNA.

\section{Enzyme degradation of coated antigens}

DNA-coated plates treated at $37^{\circ} \mathrm{C}$ for $30 \mathrm{~min}$ with the enzyme deoxyribonuclease (Sigma) resulted in complete removal of antigen from the polystyrene surface. Conversely, treatment with nuclease S1 (Sigma), which is specific for single stranded DNA, digesting double stranded DNA only at damaged sites, ${ }^{21}$ removed all the antigen from only denatured DNA-treated plates making little significant difference to those plates coated with native DNA.

\section{Colour intensity and antibody concentration}

Eleven positive sera were tested for DNA antibody activity using doubling dilutions of serum; the results were plotted and the slopes of the graphs compared (Fig. 2a). From the data it is clear that colour intensity is proportional to the amount of antibody bound to the DNA antigen and that the slopes are very similar. To demonstrate more clearly the exact nature of the slope the individual results have been superimposed around an OD of 0.75. Colour intensity is linear between optical densities of 0.45 and 1.2 (Fig. 2b). One positive serum was tested on three consecutive days to demonstrate the reproducibility of the colour reaction. The results are shown in Fig. 2c. 

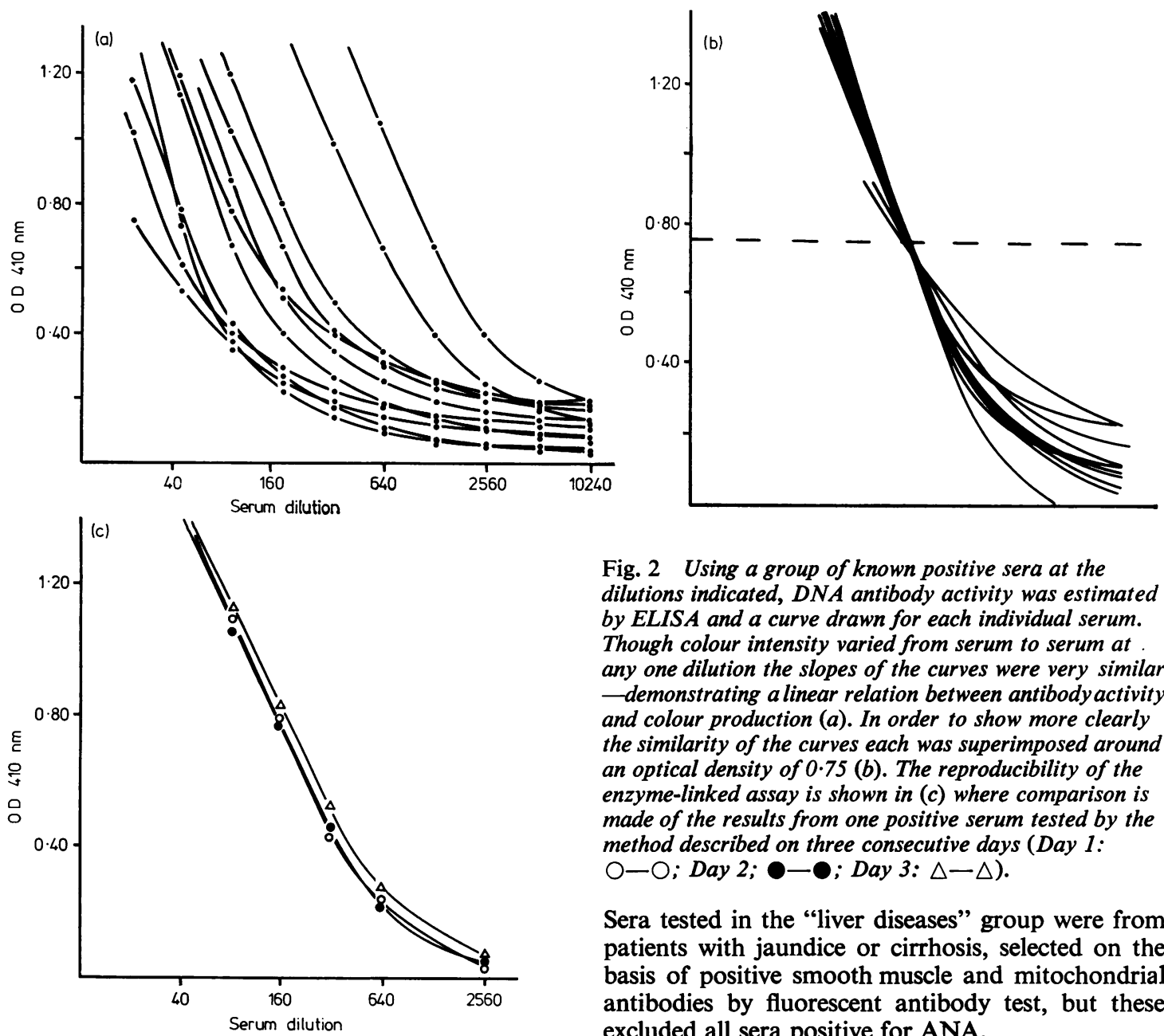

Fig. 2 Using a group of known positive sera at the dilutions indicated, DNA antibody activity was estimated by ELISA and a curve drawn for each individual serum. Though colour intensity varied from serum to serum at any one dilution the slopes of the curves were very similar - demonstrating a linear relation between antibody activity and colour production (a). In order to show more clearly the similarity of the curves each was superimposed around an optical density of $0.75(b)$. The reproducibility of the enzyme-linked assay is shown in (c) where comparison is made of the results from one positive serum tested by the method described on three consecutive days (Day 1:

O-O; Day 2; ——; Day 3: $\triangle-\triangle$ ).

Sera tested in the "liver diseases" group were from patients with jaundice or cirrhosis, selected on the basis of positive smooth muscle and mitochondrial antibodies by fluorescent antibody test, but these excluded all sera positive for ANA.

From the results in Fig. 3 it can be seen that on SERUM FROM DISEASE GROUPS

Figure 3 shows a comparison of antibody activity against native and denatured DNA between normal sera (100), sera from known patients with SLE (48), patients with liver disease (100), Crohn's disease (38) and coeliac disease (14), and rheumatoid arthritis (101). Figure 3 also shows the results of 100 consecutive sera, taken from a day's work load, and 100 other sera from patients with connective tissue and other diseases, found to have a strongly positive antinuclear antibody (titre $>1 / 100$ ), although negative for double stranded DNA antibodies by the radioimmunoassay method.

All sera were diluted $1 / 50$ in modified Tween-PBS (see Discussion). Patients from the rheumatoid group were serologically positive by standard Rose-Waaler technique. Many of these sera were also known to have a positive antinuclear antibody (ANA). the one hand not one serum in 100 normal sera was found to have any antibody activity to either native or denatured DNA and on the other not one serum in the 48 SLE sera tested using the same antigens (see under next heading) was found to be negative. Weak antibody activity in both the rheumatoid and the liver disease groups is not unexpected for it is well documented that low activities of antibodies to ANA, DNA and RNA are present in many autoimmune diseases, probably directed against the protein moiety of cellular constituents. ${ }^{22}$ Of the "random" specimens taken from the daily work load one which gave an optical density reading of 1.5 was found to be a patient with SLE.

SERA RUN IN PARALLEL WITH CURRENT

RADIOIMMUNOASSAY

During a six-month period all specimens entering 


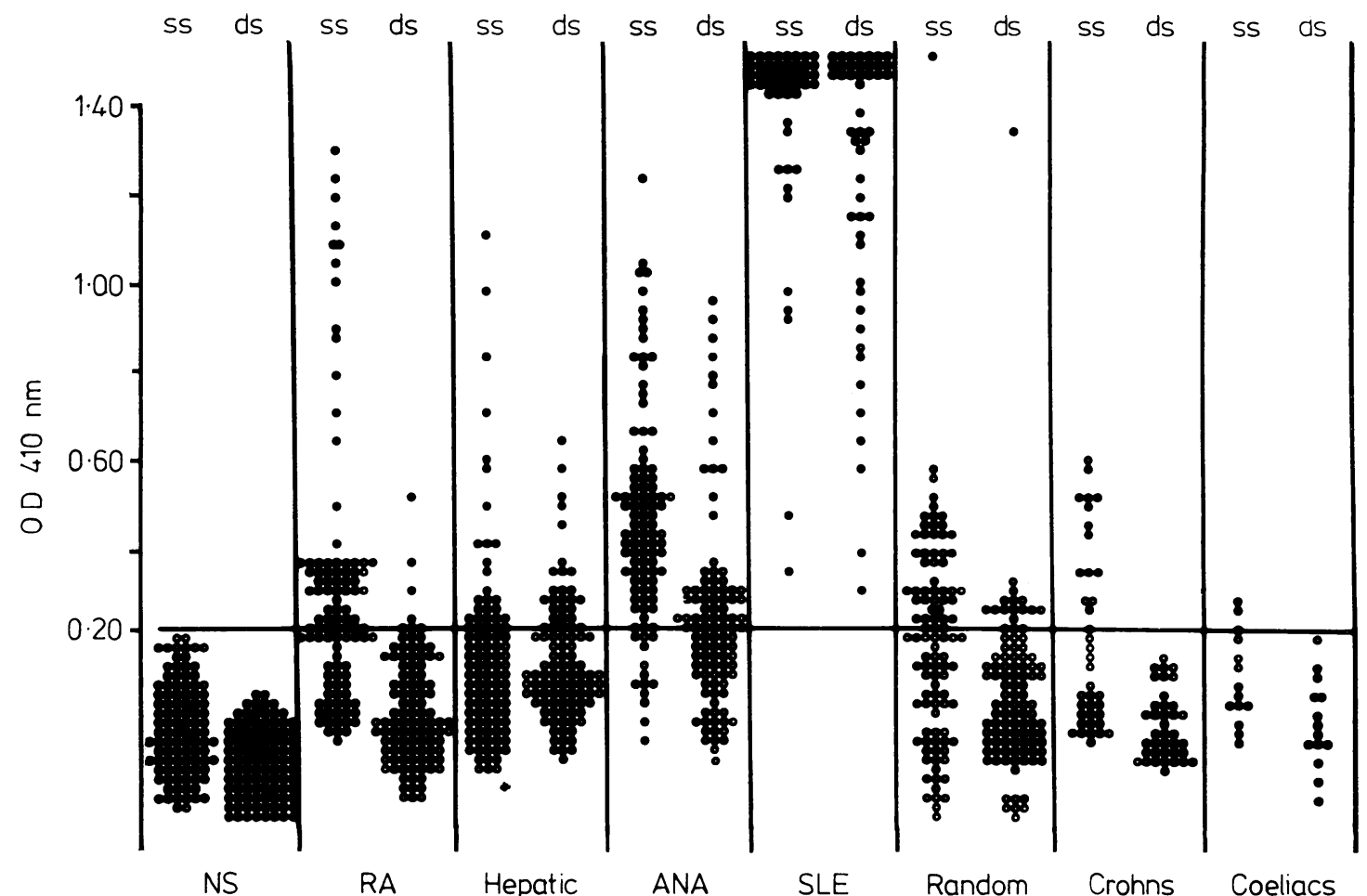

Fig. 3 Comparison of DNA antibody activity determined by ELISA found in serum from five different disease groups, a random group of hospital patients and a group of blood donors (NS). The disease groups tested were patients with serologically positive rheumatoid arthritis $(R A)$, autoimmune liver diseases (Hepatic), systemic lupus erythematosus $(S L E)$, Crohn's disease and coeliac disease. 100 sera from patients with positive antinuclear antibody $(A N A)$ were also tested. Optical density of sera diluted $1 / 50$ is shown for both native (ds) and denatured (ss) DNA. Results helow an $O D$ of 0.20 are considered to be negative.

the laboratory requesting DNA antibodies were tested by both RIA and ELISA and the results compared. It can be seen from Table 1 that agreement was reached on over $85 \%$ of all specimens tested, almost two-thirds being unequivocally negative by both tests and a further quarter, positive by both tests. Of the remaining $15 \%$ of tests only two specimens from a total of 400 were found to be consistently negative by ELISA for

Table 1 Compairson of ELISA and RIA in 400 sera sent for DNA antibody determination

\begin{tabular}{lccc}
\hline Test reaction & & Noof sera & $\%$ \\
\hline ELISA & - & 98 & $24 \cdot 5$ \\
RIA & & 56 & $14 \cdot 0$ \\
ELISA & - & 244 & $61 \cdot 0$ \\
RIA & - & 2 & 0.5 \\
ELISA & - & & \\
RIA & - & 400 & $100 \cdot 0$ \\
ELISA & - & & \\
RIA & & & \\
Total & & & \\
\hline
\end{tabular}

antibodies directed against native, double stranded DNA but positive by RIA. Both of these specimens had considerable activity against denatured DNA in the ELISA test and probably reflect the quiescence of the disease state referred to earlier. ${ }^{2-4}$ In the RIA test they were only weakly positive, at a level of antibody binding where reproducibility is poor.

Over the same six-month period 570 specimens were tested by the latex agglutination method using deoxyribonucleoprotein sensitised particles (Fisher). From Table 2 it can be seen that there is total agreement with almost $80 \%$ of sera tested and that the enzyme-linked method picks up more "positive" sera than does the latex test.

The results obtained by ELISA were compared to the results obtained by radioimmunoassay (Fig. 4). Though sera were found to be positive by both methods, the correlation of colour intensity by ELISA with percentage binding by radioimmunoassay was not always good. Some specimens exhibited a seemingly disproportionately high colour intensity 
Table 2 Comparison of ELISA and the DNP Slide Latex test in 570 sera sent for DNA antibody determination

\begin{tabular}{lccc}
\hline Test reaction & & No of sera & $\%$ \\
\hline ELISA & + & 104 & 18.3 \\
Latex & + & 117 & 20.5 \\
ELISA & + & 347 & 60.9 \\
Latex & - & 2 & 0.3 \\
ELISA & - & - & 100.0 \\
Latex & - & 570 & \\
ELISA & + & & \\
Latex & & & \\
Total & & &
\end{tabular}

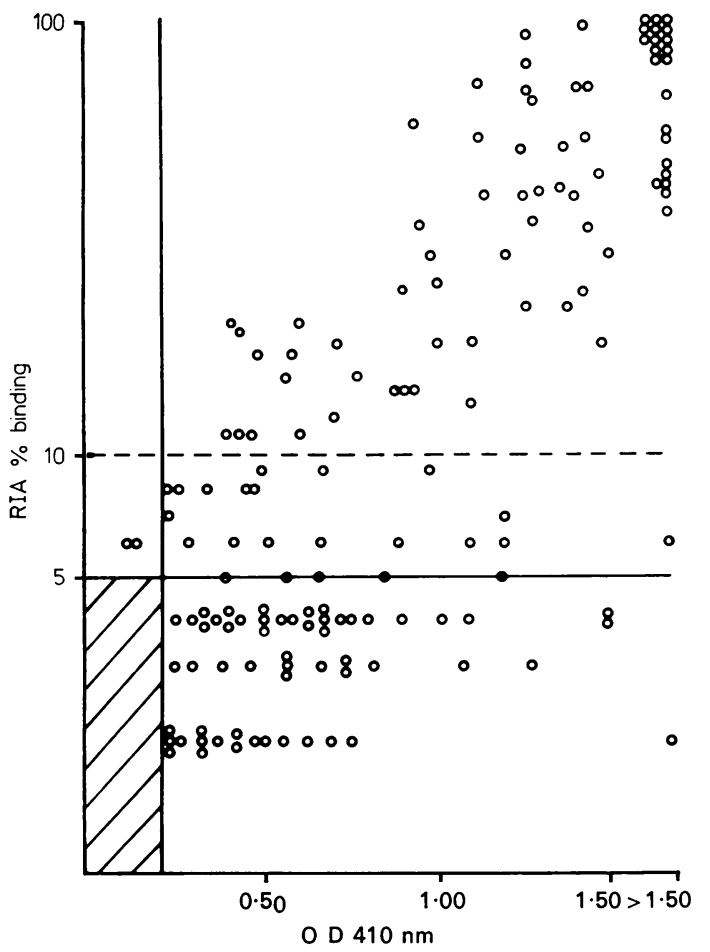

Fig. 4 Scattergram of results from serum samples estimated for DNA antibody activity estimated by ELISA and RIA to show the correlation between values by the two tests. Results below the solid line drawn at $5 \%$ binding $(R I A)$ are considered to be negative by this test whilst those above the broken line at $10 \%$ are unequivocally positive. Results below 0.20 OD at 410 (to the left of the vertical line) are considered to be negative by ELISA in the method as described. The hatched area represents results from 244 sera which were too numerous to plot individually.

compared to the DNA binding by RIA. Conversely very high binding by RIA did not necessarily yield an intense colour at a high dilution that one would ex- pect. This is not a unique finding but has been reported previously for ANA by fluorescence compared to ELISA. ${ }^{1723}$ However, all sera reacting with one preparation of DNA may not react identically with another preparation of DNA from a different source. The overall statistical correlation coefficient of results of the 76 sera positive by radioimmunoassay ( $>10 \%$ binding) tested in parallel with ELISA was $0.64(\mathrm{p}>0.001)$. Analysis of all 98 sera positive by RIA (that is, $>5 \%$ binding) gave a correlation coefficient of $0.62(p>0.001)$. The correlation was less good when results from sera that were positive by ELISA but negative by RIA were included in the analysis.

\section{Discussion}

The potential for ELISA assays to detect antibodies to DNA has long been recognised but difficulties encountered in current methodology and quantitative expression have resulted in a reticence to introduce the technique into routine laboratory practice. The present paper describes a simple, sensitive, rapid and reliable method for the quantification of antibodies to both native and denatured DNA which overcomes many of these problems.

There have been conflicting reports on the significance of antibodies to native and denatured DNA. Early reports that only sera from SLE patients reacted with double stranded DNA were followed by reports of anti-double stranded DNA in druginduced SLE, but these reactions may be due to antibodies directed not against the nucleic acid but against deoxyribonucleoprotein ${ }^{32}$ or against histone..$^{33}$ Cohen $^{34}$ and Steward ${ }^{35}$ claimed that the vast majority of SLE sera react preferentially or even exclusively with single stranded DNA rather than double stranded DNA and work by Winfield ${ }^{36}$ recorded high avidity binding to single stranded DNA but differing avidity to double stranded DNA.

A major difficulty in current techniques is the selection and preparation of the antigen to be used in the test procedure. The antigen in its pure native form is exceptionally difficult to prepare without traces of denatured, broken or nicked molecules ${ }^{28}$ and as little as $0.1 \%$ denaturation of double stranded DNA will provide sufficient antigen sites for significant reaction with antibodies to single stranded DNA. ${ }^{6}$

In a series of papers on the quantification of DNA antibodies by the Farr assay, the effects of antigen size and structure and the influence of reaction conditions on the level of DNA binding have been described. ${ }^{29-31}$

It is clear that discrepancies do arise when comparing results obtained for anti-DNA antibodies by 
ELISA to those by methods using antigen in free solution. These discrepancies may be due to antibodies directed against new antigenic determinants exposed during conformational changes imposed upon the molecule when adhering to the solid phase carrier. An alternative explanation for the quantitative anomalies may be the difference in affinity and avidity of the antibodies from various patients for the antigenic sites of the DNA molecule.

\section{REDUCTION IN BLANK READINGS}

During the initial stages of this work considerable difficulty was experienced with high blank readings when using previously published methods. This was overcome by increasing the Tween (or Triton X-100) content to $1 \%$ (vol/vol) and adding $1 \mathrm{~g} / 100 \mathrm{ml}$ bovine serum albumin to the solution used for all serum dilutions.

High blank readings were also found when plates coated with protamine sulphate were stored for subsequent use. As the method developed here added only one 30-minute incubation to a technique which could be completed in just two and a half hours all plates were routinely precoated immediately before DNA addition on the day of the test to circumvent the latter difficulty.

\section{CHOICE OF ANTIGEN}

DNA from various sources (rat liver, calf thymus, $E$ coli and herring or salmon sperm) have been used as substrate antigen by different authors. A comparison of these antigens in both native and denatured form was made using microtitre plates with and without protamine sulphate pretreatment. Though minor differences did arise there was no significant difference between the antigens employed in the described test. DNA from rat liver seemed to be more resistant to denaturation by boiling, giving consistently lower results for single stranded DNA. As calf thymus DNA is readily available commercially in an acceptably pure form this antigen was adopted for routine use.

MICROTITRE PLATES AND USE OF

PROTAMINE SULPHATE

Day-to-day variation of optical density was found to be minimal using the ELISA technique on DNA bound to polystyrene through protamine sulphate when using doubling dilutions of any one of the positive sera on microtitre plates. Changing the manufacturer or batches from the same manufacturer, made no significant difference to the results. The test was not subject to edge effect nor indeed to any positional effect within one plate. Microtitre plates designed for use in haemagglutination techniques (" $U$ " well or "V" well) were perfectly adequate for the test obviating the unnecessary expense of purchasing flat bottomed trays specifically designed for protein adherence in ELISA methodology.

EXPRESSION OF RESULTS

Direct interlaboratory comparison of quantitative assessment of antibody activity against DNA in absolute terms is at present difficult. Results are frequently expressed as percentage binding of a given quantity of labelled DNA or as a percentage of the activity of an in-house control serum which has no direct relation to any other control serum. Throughout the present paper statistical data has been calculated by comparing percentage binding of a control standard serum by RIA with colour intensity produced by ELISA using the same standard serum at a known series of dilutions. That dilution of serum yielding an optical density of 0.75 is then expressed in $\mathrm{U} / \mathrm{ml}$. The dilution may have to be mathematically derived from the linear portion of the curve. In this way any day-to-day variation in colour intensity was removed by direct comparison to the standard serum, the value of which was fully evaluated. A positive control serum is included in each DNA kit supplied by Cordis but though this serum is given a value (in IU) it is as yet related only to the WHO international ANA standard for immunofluorescent techniques.

The ELISA method offers several advantages over others currently available: (a) it is quantitative for the antibody, (b) it is cheap, (c) it does not use radionuclides, (d) it may readily be automated, (e) it is sensitive to low antibody activities, (f) it is a simple, rapid technique which may conveniently be applied to other antigens. The method overcomes the subjectivitiy of fluorescent methods using kinetoplasts which, though truly specific, are difficult to interpret in the weak positive range even by experienced personnel. Finally, in attaching the DNA molecule to a solid phase carrier through protamine sulphate one reduces the electrostatic charge which causes non-specific protein-protein interreactions in free solution. 'The development of a cheap ELISA method seemed a natural and desirable progression to enable the Department to provide an improved service in this field. Though absolute correlation of colour intensity with percentage binding by RIA has not yet been adequately explained we feel that the method described affords a simple, practical way of screening large numbers of sera for DNA antibodies. 


\section{References}

${ }^{1}$ Stollar DB, Levine L, Marmur J. Antibodies to denatured deoxyribonucleic acid in lupus erythematosus serum. II-characterisation of antibodies in several sera. Acta Biochim Biophys Acad Sci Hung 1962;61:7.

${ }^{2}$ Koffier D, Carr R, Agnella V, Thoburn R, Kunkel HG. Antibodies to polynucleotides in human sera: antigenic specificity and relation to disease. $J$ Exp Med 1971;134: 294.

${ }^{3}$ Rothfield NF, Stollar BD. The relation of immunoglobulin class, pattern of antinuclear antibody and complement fixing antibodies to DNA in serum from patients with systemic lupus erythematosus. J Clin Invest 1967;46: 1785.

4 Schur PH, Sandson J. Immunologic factors and clinical activity in systemic lupus erythematosus. $N$ Engl J Med $1968 ; 278: 533$.

5 Tan EM, Schur PH, Carr RI, Kunkel HG. Deoxyribonucleic acid (DNA) and antibodies to DNA in the serum of patients with systemic lupus erythematosus. $J$ Clin Invest $1966 ; 45: 1732$.

${ }^{6}$ Stollar BD. The specificity and applications of antibodies to helical nucleic acids. CRC Crit Rev Biochem 1975; $3: 45$.

${ }^{7}$ Pincus T, Schur PH, Rose JA, Decker JL, Talal N. Measurement of serum DNA binding activity in systemic lupus erythematosus. $N$ Engl J Med 1969;281:701.

${ }^{8}$ Adler MK, Baumgarten A, Hecht B, Siegel NJ. Prognostic significance of DNA binding capacity patterns in patients with lupus nephritis. Ann Rheum Dis 1975;34:444.

${ }^{9}$ Wold RT, Young FE, Tan EM, Farr RS. Deoxyribonucleic acid antibody: a method to detect its primary interaction with deoxyribonucleic acid. Science $1968 ; 161: 806$.

${ }^{10}$ Ginsberg B, Keiser H. A millipore filter assay for antibodies to native DNA in sera of patients with systemic lupus erythematosus. Arthritis Rheum 1973;16:199.

${ }^{11}$ Lewis RM, Stollar BD, Goldberg EB. A rapid sensitive test for the detection of antibodies to DNA. J Immunol Methods 1973;3:365.

12 Rubin RL, Lafferty J, Carr RI. Re-evaluation of the ammonium sulphate assay for DNA antibody. Arthritis Rheum 1978;21:950.

${ }^{13}$ Aarden LA, De Groot ER, Feltkamp TEW. Immunology of DNA III. Crithidia luciliae a simple substrate for the determination of anti dsDNA with the immunofluorescence technique. Ann NY Acad Sci 1975;254: 505.

14 Aarden LA, Lakmaker F, De Groot ER, Swaak AJG, Feltkamp TEW. Detection of antibodies to DNA by radioimmunoassay and immunofluorescence. Scand $J$ Rheumatol 1975;suppl 11:12.

15 Ballou SP, Kushner I. Antinative DNA detection by the Crithidia luciliae method. Arthritis Rheum 1979;22: 321.

${ }^{16}$ Whiteside TL, Dixon JA. Clinical usefulness of the Crithidia luciliae test for antibodies to native DNA. Am J Clin Pathol 1979;72:829.

${ }_{17}$ Pesce AJ, Mendoza N, Boreisha I, Gaizutis MA, Pollak VE. Use of enzyme-linked antibodies to measure serum anti DNA antibody in systemic lupus erythematosus. Clin Chem 1974;20:353.

${ }^{18}$ Engvall E. Determination of antibodies to DNA by ELISA. Lancet 1976;ii:1410.

${ }^{19}$ Gripenberg M, Linder E, Kurki P, Engvall E. A solid phase enzyme linked immunosorbent assay (ELISA) for the demonstration of antibodies against denatured, single stranded DNA in patient sera. Scand J Immunol 1978; 7:151.

${ }^{20}$ Klotz JL, Minami RM, Teplitz RL. An enzyme-linked immunosorbent assay for antibodies to native and denatured DNA. J Immunol Methods 1979;29:155.

${ }^{21}$ Shenk TE, Rhodes C, Rigby PWJ, Berg P. Biochemical method for mapping mutational alterations in DNA with S1 Nuclease the location of deletions and temperature sensitive mutations in Simian virus 40. Proc Natl Acad Sci USA 1975;72:989.

${ }^{22}$ Nakamura RM, Tan EM. Recent progress in the study of autoantibodies to nuclear antigens. Hum Pathol 1978; 9:85.

${ }^{23}$ Engvan E. ELISA, Enzyme linked immunosorbent assay. Thesis for Doctorate, Dept Immunology Wenner Gren Institute, University of Stockholm, Sweden, 1975.

${ }^{24}$ Carr RI, Koffler D, Agnello V, Kunkel HG. Studies on DNA antibodies using DNA labelled with actinomysin D (311) or dimethyl (311) sulphate. Clin Exp Immunol 1969;4:527.

${ }^{25}$ Kredich NM, Skyler JS, Foote LJ. Antibodies to native DNA in systemic lupus erythematosus a technique of rapid and quantitative determination. Arch Intern Med $1973 ; 131: 639$.

${ }^{26}$ Clough JD. Measurement of DNA binding immunoglobulins in systemic lupus erythematosus. J Immunol Methods 1977;15:383.

${ }^{27}$ Davis P, Percy JS, Russell AS. Correlations between level. of DNA antibodies and clinical disease activity in SLEs Ann Rheum Dis 1977;36:157.

${ }^{28}$ Davis P, Burrington M, Russell AS, Morgan AR. Analysis of DNA structure by Lydroxyapatite columns and ethidium bromide fluorescence techniques. A comparative study and effect on DNA binding. Arthritis Rheum 1978;21:407.

${ }^{29}$ Aarden LA, Lakmaker F, Feltkamp TEW. Immunology of DNA I: the influence of reaction conditions on the Farr assay as used for the detection of anti ds-DNA. J Immunol Methods 1976;10:27.

${ }^{30}$ Aarden LA, Lakmaker F, Feltkamp TEW. Immunology of DNA II: the effect of size and structure of the antigen on the Farr assay. J Immunol Methods 1976;10:39.

${ }^{31}$ Aarden LA, Lakmaker F, De Groot ER. Immunology of DNA IV: Quantitative aspects of the Farr assay. J Immunol Methods 1976;11:153.

${ }^{32}$ Tan EM. An immunologic precipitin system between soluble nucleoprotein and serum antibody in systemic lupus erythematosus. J Clin Invest 1967;46:735.

${ }^{33}$ Fritzler MJ, Tan EM. Antibodies to histones in drug induced and idiopathic lupus erythematosus. $J$ Clin Invest $1978 ; 62: 560$.

${ }^{34}$ Cohen SA, Hughes GRV, Noel GL, Christian CL. Character of anti DNA antibodies in systemic lupus erythematosus. Clin Exp Immunol $1971 ; 8: 551$.

${ }^{35}$ Steward MW, Olsen I, Barnett EV. Double isotope method for measuring antibodies to ${ }^{125}$ I labelled double and single stranded DNA of defined molecular weight. Ann Rheum Dis 1977;36:119(S).

${ }^{36}$ Winfield JB, Faiferman I, Koffler D. Avidity of anti DNA antibodies in serum and IgG glomerular eluates from patients with systemic lupus erythematosus. Association of high avidity antinative DNA antibody with glomerulonephritis. J Clin Invest 1977;59:90.

Requests for reprints to: Dr RA Thompson, Regional Immunology Department, East Birmingham Hospital, Birmingham B9 5ST, England. 